\title{
MOTIVATING ENGLISH LANGUAGE LEARNERS AND TEACHERS IN INDONESIA
}

\author{
IMAM KHASBANI \\ University of Bristol, United Kingdom \\ imamkhasbany.2017@my.bristol.ac.uk \\ DIDIN NURUDDIN HIDAYAT \\ UIN Syarif Hidayatullah Jakarta, Indonesia \\ didin.nuruddin@uinjkt.ac.id
}

DOI : http://dx.doi.org/10.29300/ling.v6i2.3684

\begin{abstract}
Motivation has been long believed to be an essential contributor to students' success in learning English. Many studies (e.g., Gbollie \& Keamu, 2017; Wang, 2008; Zhang \& Xiao, 2006) have been dedicated to investigating the relationship between motivation and success in learning English. While these studies have contributed to shedding light on the importance of motivation on students' achievement in learning English, insufficient research has been conducted to address the concept of motivation itself, how the concept has evolved since the first time it was developed, and to what extent motivation affects both teachers and students' performances at school. Owing to this fact, the present article seeks to discuss the notion and conceptualization of motivation by following several steps. First, the present paper took on arguments from prominent figures on the field of motivation to explore the essence of motivation and why it is essential for English as second or foreign language (ESL/EFL) learning. The conversation then built on the current theoretical framework of types and factors influencing student and teacher motivation. Following that, a plethora of discussions on the possible ways to increase student and teacher enthusiasm and motivation inside EFL classrooms were elaborated.
\end{abstract}

Keywords: English Language Learning; EFL; Extrinsic; Intrinsic; Motivation

\section{INTRODUCTION}

As one of the most used words in discussing the success of learning English language, motivation has been regarded as one of the primary and powerful ingredients of students' triumph in accomplishing classroom's goals. The word conveys so powerful meaning that it is closely tied with other words such as dedication, perseverance, ambition, and determination. As pronounced by Dornyei (2001), "motivation" has commonly been casted by many to answer educational inquiries related to the success of leaning a language. To illustrate, a question such as "Why are they eager and excited to learn English?" can be simply be answered with "Because they have a good motivation." This action, however, appear to provide simplified instance of motivation that can potentially compensate the

How to cite this article:Khasbani, I., \& Hidayat, D. (2020). Motivating language learners and teachers in Indonesia. Linguists : Journal Of Linguistics and Language Teaching, 6(2), 30-47. doi: http://dx.doi.org/10.29300/ling.v6i2.3684 
original notion of motivation which is deemed to be far more complex. Covington (2008), for example, justified the complexity of motivation by comparing it with the conception of gravity. He stated that "“[motivation], like the concept of gravity, is easier to describe (in terms of outwards, observable effects) than it is to define".

It is interesting that what Covington has argued on the complexity of motivation appears to be applicable to what many studies around motivation have been focused on. Gbollie and Keamu's (2017) study, for example, was focusing on investigating the relationship between students' motivation and their learning performances while others such as Zhang and Xiao (2006) and Wang (2008) research were trying to explain how motivation has made a tangible impact on learners' learning strategies and achievements. In a similar vein, Ho (2019) investigated and revealed that gamification inside the classroom could increase Chinese students' motivation and positively affect their academic attainment. Meanwhile, in the Iranian context, Namaziandost et al. (2019) found that collaborative learning yielded desirable outcomes for learners' performance and motivation by enabling them to approach given learning tasks by using this relatively new instructional method in Iranian classrooms. While the aforementioned research has given some attention to several issues around motivation and some extent threw some light upon a vital discussion of motivation within language classrooms, they have exclusively built a discourse upon students' motivation by only touching upon the conception of motivation at a relatively outermost layer. Little is discussed about the thorough conception of motivation and how it affects teachers' performances at schools. Addressing this matter, the present article attempted to provide an overview of motivation's conceptualization and how it has changed over time. Important issues of motivations such as how motivation can influence both teachers and students, what factors determining teachers and students' motivation at schools, and what actions should be done to boost motivation inside schoolrooms will also be reviewed and discussed.

The present-day understanding of motivation can be traced back ever since the need to explain the fluctuation phenomenon of human behaviours existed to seek confirmation. In the classical period of ancient Greek, Plato (428-348 B.C) explained that the shifts in human actions were caused by something in their head. Aristoteles (384-322 BC) further added his teacher's conception by mentioning motivation as a responsible factor that lead human reacts to events on their lives in a particular way (J. M. Cooper, 1984). The knowledge enjoys significant development ever since and has been closely related to other work of knowledge, such as Marlow's work on human needs. Marlow (as cited in Griffin, 1994) proposed a theory of "Hierarchy of Needs". The need that every human in this world is longing to satisfy is labelled into five different levels. At the bottom level is the human's need for psychological Linguists: Journal of Linguistics and Language Teaching Vol. 6, No. 2, December 2020 
satisfaction that is followed by the human's need for feeling safe, being loved, feeling respected and self-actualization. These needs act as a powerful force that drive to do certain activities in our lives.

Despite the fact that the theory is still debatable and poses some questions (e.g., does presence of lower level of human's need act as a prior condition to the higher level? Will the lack of the need of being love, for instance, negate people's need to be respected?) it provides as a basic rational and knowledge on how motivation is associated with learning English language. It can be speculated that the need of people to learning a new language, such as English, falls into the highest level of human's need that is self-actualization. As stated by Pennycook (1994), English acts a "a gatekeeper to a position of prestige in society" (p.14). It is argued that the language will provide its speakers higher chances of having better lives by offering more opportunities to better occupations and educations. This phenomenon is arguably to be tightly linked with globalization. An access for people to travel worldwide and communicate with others coming from different cultural backgrounds and languages has urged many to learn English and has eventually facilitated English to be "the unquestioned and uncontested global language" (Giampapa \& Canagarajah, 2017, p. 1). As the world witnesses a notable growth of numbers of English language learners, the need to find a way that can facilitate an effective English language learning has never been obvious and higher. Many studies have been conducted to address this matter. Some have leaned their focus the teaching methods and materials while others are more interested in studying the personal aspects of learners such as motivation.

In the realm of language learning and acquisition, the earliest concept of motivation is the notion of integrativeness or integrative. As described by Gardner and Lambert (1956, as cited in Gardner, 1985a), integrativeness refers to motivation that is "characterized by willingness to be like valued members of the language community" (p. 271). English learners with intergrative motivation can be indicated by their ambition to learn English in order to be able to interact and involve with people from English speaking countries by, for example, making friend with them or being a member of their community. Gardner (1985a) strongly inserted the need of integrativeness in learning English by stating that the succed in mastering English language is determined by learners' ambition and attachment to the language. He went on to argue that intergrative motivation can help grow students' postive feeling and attitude towards the language they are trying to master, which is able to keep their motivation at its highest level. Owing to the vitality of intergative motivation in learning English at that time, this conceptualization served as the main reference of many studies in the area of 
language learning and motivation. Gardner (1985a) futher developed his theory on intergativeness into The Attitude/Motivation Test Battery.

The theory, however, did not go unchallenged. Many doubts were aimed at the practicality of this theory in the educational field. Dörnyei (1994), for example, casted doubt on the feasibility of Garden's theory of integrativeness by stating that the theory is too socialcenter and neglects other important aspects of language learning and acquisition in classrooms. Although Intergativeness theory takes into account teachers' competence and rapport and material evaluations, it fails to include learners' mental process, making it impractical to be utilized as a holistic ground to evaluate learners' motivation in learning English language. This fact has later prompted Ushioda and Dörnyei (2009) to denounce the use of intergrativeness concept in the study of second language acquisition and English language teaching and learning for the reason that the concept "was rather limiting and, quite frankly, did not make too much sense in many language environment" (p. 10). With all doubt and criticism that have been casted on Gardener's theory of integrativeness, it appears that in the present time the theory does not enjoy the same popularity as it did in the past. Recent studies on language learning and acquisition appear to primarly utilize L2 Motivational Self System theory proposed by Dornyei. This theory underlines the contribution of students' cognitives and a variety of students' achievement sources on their overall motivation in learning English language (Dörnyei, 2001; Ushioda \& Dörnyei, 2009).

\section{METHOD}

Research on motivation in the EFL area has accelerated rapidly since this concept was first introduced a few decades ago. While this phenomenon can be regarded as a good sign where the knowledge production of motivation is still kept alive, it at the same time can potentially pose a problem where the existing knowledge is fragmented in a particular research area. Responding to this matter, Synder (2019) posited that a literature review is the answer to the problem as this research methodology enables researchers to "provide an overview of areas in which the research is disparate" (p. 333). Generally defined as a method of gathering and synchronising readily available data from previous studies, literature review possesses the power that no other methodologies might have, such as the flexibility to synthesise data from a large number of research studies, the ability to address some uncovered parts of knowledge that are not likely to be done in a single study, and the capacity to allow a researcher to provide either narrow or broad overviews in a particular research problem to facilitate theory developments (Tranfield et al., 2003; Webster \& Watson, 2002).

For this reason, the present article decided to employ a literature review study as the main purpose of this article is to provide an overview of motivation in the EFL area. In doing Linguists: Journal of Linguistics and Language Teaching Vol. 6, No. 2, December 2020 

so, the present study put to use an integrative review approach in writing the article. As explained by Synder (2019), an integrative review is used when the purpose of the study is to review, assess, and synthesise published literature to compare and combine diverse perspectives from different studies. As this article aimed at describing how the conception of motivation in education has changed over time, information, and data documented by prominent researchers from this field, such as Gardner and Dörnyei, were utilised. This information and data were compared and synthesised to reveal both similarities and differences. This paper used data from relevant previous studies set out in different academic contexts to support the discourse of motivation and provide divergent perspectives.

\section{FINDINGS AND DISCUSSION}

\section{What is Motivation in Language Learning, and Why Does It Matter?}

Motivation is thought to be a complex and multi-dimensional language learning construct. Attempts have been made in the past to define this notion. Feldman (2010) pronounced that motivation is an ultimate force that stimulates both people's biological and physical responses that lead them to perform certain actions to reach their highest level of achievement on cognitive and social aspect of lives. Bearing this in mind, it is indicative that in learning a language motivation can help students succeed not only in mastering the language but also in using in real practice. Those who are unfamiliar with the concept of motivation and its role in English language, however, might propose questions such as: "How could motivation help student to learn English language? What is the rationale underpinning this phenomenon?" Academic research have been conducted to respond to the questions and it is aggred that motivation plays a vital role in securing students' success in learning English language by:

\section{Performing as an agent to promote learning autonomy}

Firstly developed 40 years ago at the University of Nancy (Najeeb, 2013), the concept of learning autonomy is widely regarded as an exemplary learning situation. Smith (2008) described learning autonomy as a condition where learners possess authority over their learning condition that makes them more independent and less dependent on their instructors or teachers. In relation to language learning, Ushioda (2011) was of belief that motivation can perform as an agent to promote learning autonomy and provide students with more freedoom to learn and practice their language mastery. That is to say, learners who are motivated tend to be independent and willing to learn and exercise their language skills outside the classroom settings. This type of student believes that learning a languge should not be done exclusively 
with the presence of an instructor or teacher and practicise a language should not be limited to classroom engagement.

\section{Stimulating Self-regulated Learning}

As the legacy of Paul R. Pintrich in the field of educational psychology (Schunk, 2005; Wigfield et al., 2005), self-regulated learning (SLR) is defined as "an active, constructive process whereby learners set goals for their learning and then attempt to monitor, regulate, and control their cognition, motivation, and behaviour, guided and constrained by their goals and the contextual features in the environment" (Pintrich, 2000, p. 453). SLR helps learners to actively engage in learning activity and "adapt their thoughts, feelings, and actions as needed to affect their learning and motivation...[and] to reach learning and performance goals" (Boekaerts \& Corno, 2005, p. 201). It is indicative that throughout their learning processes, English language learners might be encountered with various events that can possibly alter their reaction and attitude toward learning activities. In this occasion, learners' ability to adapat their thought and feeling is required. Motivation can postively impact students'capability in regulating and manipulating their feelings. Motivated students are able to thrive in an unfavourable learning situation while still focusing on their learning goals (Zimmerman, 1989).

Academic research has been performed to support this assertion, such as the works of Seker (2016) and Mahmoodi et al., (2014). After investigating 222 English as a foreign language (EFL) learners in one of state universities in Turkey, Seker (2016) found out that SLR significanly and positively impacted the participants' language learning achievement. In the same vein, Mahmoodi et al. (2014) also discovered in their study on 130 EFL students that SLR and motivation create a a strong and positive link with each other. They argued that motivation helps the participants to create their learning goals and define achievable steps while SLR helps them to keep persistent thought throughout goal-achieving processes.

\section{Creating positive classroom atmosphere}

Classroom is a vital enviroment for students to learn English language as it is the place where students will spend almost all their learning time to study and master the language. Needless to say, it is mandatory that teachers need to create a postive classroom atmoshere where there are no intimidations and threats present towards students. According to Cooper and McIntyre (1996), a positive classroom setting can only be established when there is a harmonious interaction between learning participants and learning environments. The action of creating harmonious interactions, however, is not exclusively teachers' responsibility. That is to say, students' participations are also required. In this regards, motivation is able to reinforce positive attitude from students to create favourable learning atmosphere as motivated students are more likely to keep learning activities in order. In Linguists: Journal of Linguistics and Language Teaching Vol. 6, No. 2, December 2020 

addition to that, motivated students also tend to help create conducive learning environment by actively participating in learning process, sharing opinions and helping their classmates (Abdullah et al., 2012). It is worth to note, hoewever, that motivation and postive classrooms environment are dependent to each other and thus create a bi-directional relationship. In this sense, positive classroom settings can motivate students' participation inside classrooms and on the other hand motivated students' participation can help establish favourable classroom conditions. Thus, it is worth noting that in creating positive classroom enviroment considering both factors is essential as they can lead students into an enjoyable and successful learning path. Teachers should be able to create a comfortable atmosphere inside the classrooms and at the same time build and maintain motivations in students because with the absence of motivation, students might not have a clear rationale why they have to engage in particular learning activities (Noels et al., 2000).

\section{Factors Determining Students' Enthusiasm to Learn English}

Motivation plays a pivotal role in students' performances inside language classrooms as "it can influence what, when, and how we learn" (Pintrich \& Schunk, 2000, p. 6) and at the same time, acts to provide simultaneous energy and desire for students to study and achieve their learning goals (Gbollie \& Keamu, 2017). Popular theoretical conceptions have categorised motivation into two different types: intrinsic and extrinsic motivations. As put forward by Gardner (1985b), intrinsic motivation is the type of motivation that is mainly driven by internal rewards. Students with intrinsic motivation, for example, find studying a language rewarding because they feel an internal satisfaction and enjoyment by engaging in learning activities. On the other hand, extrinsic motivation highly relies on external factors and is often utilised as "a means or way to achieve target" (Mahadi \& Jafari, 2012, p. 233). Extrinsically motivated students, for example, are willing to sacrifice their time studying to pass a test. Although these two motivations are often viewed as "a binary opposition" (Takahashi, 2018, p. 170), intrinsic motivation is often regarded as more favourable in learning situations than the other. They play an equally crucial part in determining students' attitudes toward the English language inside classrooms. As postulated by Pintrich and Schunk (2000), motivation highly depends on time and context. Students studying in different learning environments might exhibit different motivations toward the same subject. Therefore, it is safe to argue that their perception of learning activities influences students' motivation. Besides, Ichikawa (2001) also stated that learners' age also plays a big part in maintaining students' learning motivation. He went further to argue that motivation can change with the age of students. Students who find one learning activity enjoyable when they were young might show different reactions when being involved in the same activities as they 
become older. To conclude, students' motivation to engage in academic activities is dependent on how they view the subject they are being exposed to inside the classrooms and what stage of life they are at when they receive the learning materials. In the language learning context, one can narrow down the argument about what influences students' enthusiasm to learn English to learners' perception of English and their age.

\section{Learners' Perception of English}

It is generally assumed that students will be highly motivated to learn a language if they are benefited from learning activities and vice versa. To prove the assumption, a considerable amount of research has been focused on bringing out into the open this seemingly close relationship. Chen et al. (2005), for example, argue that students' indifferent attitude toward learning English language in Asian EFL (English as a Foreign Language) countries stems from the questionable possibility of the future language use and the absence of engagement opportunity with the target language in the countries. To illustrate, some Asian countries like Indonesia, Japan, Thailand, and Laos do not recognize that this article is written, the possibility of English being widely spoken by the general public. Consequently, students are often discouraged from learning the language as they do not see the practical benefit they can gain. This phenomenon seems to be in consonance with an assertion expounded by Mesthrie and Bhatt (2008), which argues that English in EFL countries only "plays a role for mainly inter-national rather than intra-national purposes" (p. 5). Unless students can use the language internationally (e.g., working abroad or studying in Englishspeaking countries), it is very unlikely that the language will become a part of their daily lives.

Similiarly, Kormos and Csizér (2014), after carrying out research that focuses on examining the mutual relationships of self-regulatory strategies, motivation, and autonomous learning on three different groups of Hungarian learners, confirm the importance of learning environment and students' perception in shaping their enthusiasm for language learning. Students who have a positive perception of English will more likely to develop autonomous learning behaviour. They will independently learn the language outside the classroom and advance their language skills using any available resources.

\section{Learners' Age}

It has been long argued that age differences might influence how students see the classroom activities and affect their willingness to engage with them. Numerous studies have been carried out to explore this topic. Among the earliest research studies on this issue are Weiner and Peter (1973) and Weisz (1980). Having evaluated performances of three hundred students aged 4-18 years old, Wiener and Peter learned that younger students showed a tendency to measure their learning success merely by the learning outcome such as grades. Linguists: Journal of Linguistics and Language Teaching Vol. 6, No. 2, December 2020 
They speculated that students under the age of 12 years tended to solely see their learning achievement in terms of success and failure or are good and bad marks or the number of stars they received inside the classrooms.

Meanwhile, among students of the age older than 12 years, learning outcome becomes an essential key factor in academic-related environment. The amount of effort the students put into their study also plays no less important role. Older students in the research were likely to be aware of a positive correlation between study and academic success determinations.

In a somewhat similar fashion, Weisz (1980) investigated how students' developmental changes impact their perceived judgments towards academic outcomes. After involving kindergarteners and fourth graders in the study and asking them on what factors are likely to govern their success, it was found that younger students, compared to their older counterparts, tended to see success due to high competence-related factors as intelligence, practice, and concentration. In this case, young students are likely to believe that accomplishing one's goals highly depends on their internal factors. The more practices they get, the higher chances for them to achieve their favourable outcomes. In contrast, the fourth graders in this study recognised that internal factors are not the sole component contributing to ones' success. They started the role of external factors such as lucks that could determine the achievement of positive results. Regarding this research outcome, Weisz (1980) confirmed the role of developmental changes and age in influencing how students perceive their academic outcomes and judge their behaviours to achieve the desired result.

More recent studies also show a significant correlation between students' maturity and their motivations inside English as a second language (ESL) classrooms. A study conducted by Bećirović and Hurić - Bećirović (2017) on 210 students aged eighteen, fourteen, and ten, for example, revealed that intrinsic motivation decreases with age while extrinsic motivation shows an increasing trend as students become older. The result appears to confirm the arguments of the previous studies on how motivations vary across different age levels. The developmental stage of students' lives influences how they see the world and perceive learning activities inside the classrooms. It is argued that as students grow older and become mature, they expand their needs that will later shift their purposes of study and alter their academic motivation.

\section{Developing Motivation}

All information that we have on the importance and multifceted nature of motivate should lead us on the discussion of the feasibility of motivation in safegurading students' success in learning English language. Thus, questions around the best methods to maintain 
students' motivation should be placed now at the forefront of our attention. There is no one research finding that answers the query the best. For that reason, drawing information from various empirical investigations become inevitable, and below are strategies teachers could implement in the classroom:

\section{Maintaining Students' Ideal Self}

Given you are a physic teacher that has to teach a third-grade students about the concept of rainbow, what would you possibly do inside the classroom to have your students take an interest in the subject? Would you talk about the abstract concept of a rainbow or would you rather show the class a picture of a rainbow? Many might possibly select the latter option and there is a logical reason for it. It has been agreed that providing students with teaching media such as picture or video can facilitate their visualization about the subject being learned inside the classroom. Teaching media also allow students to imagine and create visual imprint of an abstract concept of a subject in their mind that can in turn develop their interest to learn more about the subject.

In the realm of language learning and acquisition, the idea of the ilustration given above is formed as L2 Motivational-System. This concept defines motivations into two diferrent categories: ideal self and ought-to self (Ushioda \& Dörnyei, 2009). Ideal self refers to the state of what students expect to achieve by master the language they are learning. In this case, ideal self defines what values learners are willing to ascribe by learning a language. This value is often linked to personal and social attributes. Meanwhile, ought-to self can be established a value that language learners have to have by learning a language. Unlike that of ideal self, the value on ought-to self is ascribed to learners not because they want to but because they have to as they need to represent obligation or responsibility (Boyatzis \& Akrivou, 2006; Dörnyei et al., 2006). To illustrate, students who possess an ideal self while learning a language might visualise the ideal version of themselves and the societal value and economic benefit they are finally able to gain when they become fluent in the target language.

On the other hand, students driven by ought-to self-motivation will likely be aspired to learn a language because they will not be able to have a good grade and pass an exam without doing so. Learning a language in this situation is seen as duty and obligation. Bursal and Öz (2017) simplify that ideal self-motivation focuses on the learners' future expectations while self-motivation revolves around students' present experiences.

Numerous studies have been carried out to confirm this conceptualization of student motivation. Lamb (2007), for example, investigated 219 participants on his study in one of Indonesian school in Sumatra. He revealed that the primary reasons the participants in his study to learn English are to interact with English speaker and learn the culture of the target 
language. It is indicative from the reasons given by the participants that learning English adds value to their personal lives. He argued that learning English has potentially increased the chance for the students to have a broader and more diverse interactions and, at the same time, enrich their cultural knowledge of English speaking countries. The students in the study indeed presented their confidence in learning English by stating that they can view themselves as better than others who do not have the same chance to study the language. It appears that having a more desirable future is the underlying motive of why students are willing to spend many hours learning about and exercising to use English.

In addition to that, an additional reason of why the participants learn English emerged from the study. The reason is because their parents demand them learn the language. Parental involvements, as the study speculates, play no less vital role in this matter. Often, parents exercise their authoritative power to encourage their children to be more actively involved in English learning activities. Concern over their child's future and pressure from globalisation underpin this behaviour. The parents' preconceived opinion towards globalisation exerts considerable influence on the students' thoughts of the significance of English for their future lives. There seems to be a growing consensus that having sufficient English language skills can help students negate the detrimental impact of globalisation and yield the full benefit of this global phenomenon in the future. The finding of Lamb's study appears to illustrate and validate the concept of ideal-self and ought-to self motivations. It, however, poses new questions. Does the learning context highly exert an influence on students' motivation? Do learners living in a place where globalization does not play a central role possess the same level of motivation as the Indonesian students in Lamb's (2007) study?

The answers to the above inquiries, apparently, were proposed several decades ago. Gardner, (1985b), after conducting an investigation on students' attitudes towards learning French language, argued that learning environments generally control students' integrative motivation. He went on to argue that different learning settings exert different opportunity for students to exercise the language and "that opportunities to use the language can have a profound effect on the composition of these major dimensions [motivation and language aptitude]" (p. 67). Another study that helps shed light on this issue was the study done by Taguchi et al. (2009) on students in Japan, Chinese, and Iran. The study reports that the language learning motivation level in the three countries exhibits a stark contrast, with Japanese students showed the lowest level among all. The facts that English fails to play its salient role as a social gatekeeper in Japanese society and that mastering English in China and Iran is strongly linked to a higher chance of securing a place in a better workplace and having a better future help explain why Japanese students tend to be less successful in maintaining 
their interest in learning English language than their Chinese and Iranian counterparts. Considering the findings of the above studies, it would sound reasonable to argue that students from a country with an intensive relationship with the English language would likely be motivated to master the language than those studying in the context where the future use of English is still debatable.

With that being the case, one might now ask what English teachers should do to keep motivating students from a place where English might not have a considerable influence on students' present and future lives. Yashima (2009), after investigating English learning motivation on 191 Japanese high school students, reveals that international posture (an inclination to be a part of a target language community and to engage in its interactions) exhibits a strong relationship with students' ideal L2 self. Thus, he suggested that help students envision how they could be a good fit for the imagined international community can lead to a higher frequency of language practices. Similarly, based on his research on $200 \mathrm{ESL}$ students, Abdullah et al. (2012) learned that the ideal self is a major factor contributing to students' learning motivation. He argued that ESL learners capable of building ideal-self have a bigger imaginative capacity that significantly contributes to their ability to picture themselves in a potent ideal language. Those who can represent themselves in ten years, for example, are at a better chance to draw specific goals and generate heightened motivated behaviors to put their self-imagination into reality.

\section{Enacting the Concept of Possible Language Teacher Self into Language Teacher}

\section{Development Program}

In an educational setting, teachers also conduce to the forming process of students' motivation. Teachers' beliefs on what language learning is and how it should be directed are embedded in their actions that affect how they express themselves. The atmosphere of the classroom to which students respond and feeling is accentuated. In short, teacher actions influence students' feelings, and those feeling contribute to forming students' motivation. The central theme of the above conception can be framed into the idea of Possible Language Teacher Self, which is primarily extended from Markus and Nurius (1986) work on the “Possible Self” construct. They theorized that "[possible] selves represent individuals' ideas of what they might become, what they would like to become, and what they are afraid of becoming, and thus provide a conceptual link between cognition and motivation" (p. 954). In Second Language Acquisition (SLA) and Foreign Language Learning (FLL) fields, Kubanyiova (2009) speculated that how teachers set a standard of the possible figure they want to become (ideal language teacher self), perceive their duties and responsibilities on the actual condition on their working environment (ought-to language teacher self), envision another possible figure they could become if the previous two figurative versions fail to meet Linguists: Journal of Linguistics and Language Teaching Vol. 6, No. 2, December 2020 
(feared language teacher self) comprise how teachers see the ideal version of themselves (Possible Language Teacher Self).

Arguably, teachers who can effectively utilize all of the aforementioned possible figures will find themselves self-conscious of their motives to pursue the teacher career and thus impact their effort to take part in teacher development. As postulated by Kubanyiova (2009), generally, what motives a person to pursue a career as an English teacher falls into two main categories. The first motivation centers primarily on the person's attitude toward the English language. As widely discussed, those holding a positive view toward English and aspire to improve their skills and proficiency in the language will be more likely to maintain their job and grow professionally when choosing ESL or EFL teaching as their profession. In contrast, those who exhibit a negative attitude toward the English language and its teaching are likely to change their career path along the way and not survive the teaching jobs for an extended period of time or, even worse, show a lack of motivation in the workplace. However, one should note that attitude is not the sole factor motivating people to work as an English teacher. As further stated by Kubanyiova (2009), another primary motive that inspires people to pursue their teaching career is closely related to psychological needs. Those were striving for recognition, authority, respect, and appreciation view that teaching job can be an effective medium to fulfill their needs. Working at schools where interactions with others are widely available gives teachers opportunities to be recognised, respected, valued, and appreciated for their students, peers, and parents' works. Moreover, having full control of what happens inside a classroom also provides teachers with a sense of authority.

Acknowledging what motivates English teachers to choose their job is crucial as these motivations are always reflected in their classroom behaviours. What is more important than merely recognising these motivations is maintaining and equipping them to yield positive impacts on English teaching and learning activities. In Thailand, Syamananda (2017) learned from one of his research's key findings that EFL teachers highly value well-maintained interpersonal relationships with colleagues and students. The feeling of relatedness where EFL teachers can have meaningful interactions with other staff exerts considerable influence on teachers' attitudes and motivations in the workplace (Nias, 1981). Having daily conversations or routinely planned activities from which EFL teachers and their coworkers can draw authentic engagements and healthy emotional connections are suggested (Bradley, 2010). Not only can this action help create a desirable atmosphere on the worksite, but it can also elevate EFL teachers' motivations and keep them at their high level. While the need to maintain desirable connections is intrinsically wired, other studies point out that external factors contribute to EFL teachers' enthusiasm at work. Johnson (2000), for example, points 
out that the exposure to new teaching concepts and ideas, the availability of teaching resources, and the continuous supervision help boost teachers' enthusiasm not only in getting their responsibilities done but also in making sure that they are executed well.

What is more, many researchers have also found out that teachers will be more likely to be satisfied at work and perform better when they are given the freedom to manage the classrooms while at the same time also provided with continuous teacher development programs (Barrs, 2005; Butler, 2007; Crookes, 1997). Arguably, allowing English teachers to decide what teaching materials and activities to be delivered and involved inside the classrooms gives English teachers a sense of authority, which is mentioned in the previous discussion to be one reason people choose a teaching job. Osman (2013) termed this flexibility in teaching as "academic freedom" (p. 142). He regarded academic freedom as a fundamental component in language teaching and learning because of its ability to induce teacher creativity to flourish. He further argues that teachers who can choose teaching materials beyond mandated coursebooks are more seemingly responsive to students' different needs and abilities inside the classrooms and capable of selecting appropriate learning materials and aids. To this point, one could argue that the ability to assign appropriate resources inside the classrooms will later influence the effectiveness of teaching and learning activities and motivation for both teachers and learners. Students who feel comfortable to engage with others will help create conducive classroom atmospheres, which in turn boost teachers' enthusiasm and motivation to deliver lessons.

\section{CONCLUSION}

Motivation is, beyond doubt, an extremely vital factor in determining the successful conduct of teaching and learning activities both for teachers and students. The complex nature of motivation had made it previously difficult for educational practitioners to grasp and measure learners' psychological stimulation. For decades, many studies have been set out to explore and better understand the fundamental tenets of motivation. The present study highlighted four major findings from the above discussion. The first is the substantial changed of the conceptualization of motivations from the early theory of integrativeness to the latest L2 Motivational Self System theory. Unlike the former, the latter theory has put the complex nature of students, such as their learning environments, into consideration when defining and measuring their learning motivation at school-the second finding centres around the nature of motivation and its paramount importance to language teaching and learning.

As discussed, we currently understand the vital role of motivation as the promoting agent for student self-regulated and autonomous learning and the factor encouraging Linguists: Journal of Linguistics and Language Teaching Vol. 6, No. 2, December 2020 
conducive atmospheres inside classrooms. Due to these benefits, teachers need to turn their attention over planning and initiating activities that can motivate students to learn the English language. The third finding underlines the types of motivation and factors determining its level of students. We have apprehended currently that on the basic principle, motivation is classified as intrinsic and extrinsic. While intrinsic motivation is tightly wired to the internal factors, external motivation, as then name tells, depends largely on the outside factors of a student. Acknowledging that the two kinds of motivation are distinct is of paramount importance for English teachers as each motivation comes with their peculiarity and requires different treatments. The above discussions have highlighted factors underpinning levels of student motivation in English language classrooms. Students' maturity and their beliefs on English's contribution to their future lives play a significant role in their level of academic engagement inside classrooms. Teachers need to adjust their classroom activity to best suit their students' age and, at the same time, increase their level of motivation.

While much attention has been diverted to leveling up student motivation inside the classrooms, one should also be aware that teacher motivation also plays a significant part in ensuring the attainment of English language learning outcomes. This issue is what the last finding of this article talks through. Maintaining teachers' best performance should be prioritised by all educational actors at schools. Many educational researchers (e.g., Acton \& Glasgow, 2015; McCallum \& Price, 2010) have suggested that to manage professional flourishing, we need to improve teachers' well-being at work by, for example, encouraging positive relations between teachers and coworkers and facilitating open and warm interactions between teachers and students. Moreover, increasing teachers' motivation and productivity can also be done by including teachers in schools' decision-making processes (Jongmans et al., 1998). As those having first-hand interaction with students, English teachers, and all teachers in general should always be involved in school policy-making as their voices likely reflect the real situation that occurred to learners inside the schoolrooms. In doing so, school authority can, for example, ask teachers to discuss about the institution or classroom program goals and formulate learning objectives and offer flexibility in conducting academic activities. To conclude, quoting Johnson (2000) statements, it is essential to note that collaborative efforts among English language educators and stakeholders is important as it "spreads the rights and responsibilities for learning to teach among all those who participate in and have an impact upon it. It forces all those who are involved to recognize and communicate with one another, to establish common bonds and goals, and to build on each other's strengths to foster teacher learning and professional development in a range of instructional contexts". 


\section{REFERENCES}

Abdullah, M. Y., Bakar, N. R., \& Mahbob, M. H. (2012). Student's participation in classroom: What motivates them to speak up? Procedia-Social and Behavioral Science, 516-522.

Acton, R., \& Glasgow, P. (2015). Teacher wellbeing in Neoliberal contexts: A review of the literature. Australian Journal of Teacher Education, 40(8), 99-114.

Barrs, J. (2005). Factors contributed by community organisations to the motivation of teachers in rural Punjab, Pakistan, and implications for the quality of teaching. International Journal of Educational Development, 25(3), 333-348.

Bećirović, S., \& Hurić - Bećirović, R. (2017). The role of age in students' motivation and achievement in learning English as a Second Language. JoLIE Journal, 10(1), 23-35.

Boekaerts, M., \& Corno, L. (2005). Self-Regulation in the classroom: A perspective on assessment and intervention. Applied Psychology: An International Review, 54(2), 199-231.

Boyatzis, R. E., \& Akrivou, K. (2006). The ideal self as the driver of intentional change. Journal of Management Development, 25(7), 624-642.

Bradley, C. A. (2010). Exploring relationships between EFL teacher motivation, meaningful content, and learner motivation. Journal of the Faculty of Global Communication, 11, 1-10.

Bursal1, N., \& Öz, H. (2017). The relationship between ideal L2 self and willingness to communicate inside the classroom. International Journal of Higher Education, 6(4), 229-239.

Butler, R. (2007). Teachers' achievement goal orientations and associations with teachers' help seeking: Examination of a novel approach to teacher motivation. Journal of Educational Psychology, 99(2), 241-252.

Chen, J. F., Warden, C. A., \& Chang, H. T. (2005). Motivators that do not motivate: the case of chinese EFL learners and the influence of culture and motivation. TESOL Quarterly, 39(4), 609-633.

Cooper, J. M. (1984). Plato's Theory of Human Motivation. Histoy of Human Philosophy Quarterly, $1(1), 3-21$.

Cooper, P., \& McIntyre, D. (1996). Effective teaching and learning: Teachers' and students' perspective. Open University Press.

Covington, M. V. (2008). The will to learn: A guide for motivating young people. Cambridge University Press.

Crookes, G. (1997). SLA and language pedagogy: A socioeducational perspective. Studies in Second Language Acquisition, 19(1), 93-116.

Dornyei, Z. (2011). Teaching and researching motivation. Longman.

Dörnyei, Z. (1994). Motivation and motivating in the foreign language classroom. The Modern Language Journal, 78(3), 273-284.

Dörnyei, Z. (2001). Motivational strategies in the language classroom. Cambridge University Press.

Dörnyei, Z., Csizér, K., \& Németh, N. (2006). Motivation, language attitudes and globalisation: A Hungarian perspective. Multilingual Matters.

Dörnyei, Z. (2001). Teaching and researching motivation. Essex: Pearson Education Limited.

Dörnyei, Z. (2009). The L2 motivational self system. In Z. Dörnyei, \& E. Ushioda (Eds.), Motivation, Language Identity, and the L2 Self (pp. 9-42). Bristol: Multilingual Matters.

Feldman, R. S. (2010). Understanding Psychology. McGraw-Hill Higher Education.

Gardner, R. C. (1985a). Social Psychology and Second Language Learning: The role of attitude and motivation. Edward Arnold.

Gardner, R. C. (1985b). The Attitude/Motivation Test Battery Technical Report. University of Western Ontarion.

Gbollie, C., \& Keamu, H. P. (2017). Student academic performance: The role of motivation, strategies, and perceived factors hindering liberian junior and senior high school students

Linguists: Journal of Linguistics and Language Teaching

Vol. 6, No. 2, December 2020 
learning. Hindawi Education Research International, 1-11.

Giampapa, F., \& Canagarajah, S. (2017). Skilled migration and global English. Globalisation, Societies and Education, 15(1), 1-4.

Griffin, E. A. (1994). First look at Communication Theory. McGraw-Hill Publishing Company.

Ho, J. (2019). Gamifying the flipped classroom: How to motivate Chinese ESL learners? Innovation in Language Learning and Teaching, 1-5.

Ichikawa, S. (2001). Manabuiyokunoshinrigaku (Psychology of learning motivation). PHP Institute.

Johnson, K. E. (2000). Innovations in TESOL teacher education: A quiet revolution. In K. E. Johnson (Ed.), Teacher Education-Case Studies in TESOL Practice Series (pp. 1-7). Teachers of English to Speakers of Other Languages.

Jongmans, C. T., Beijaard, D., \& Biemans, H. J. (1998). Teachers' involvement in school policymaking and the effectiveness of schools' in-service training policy: Results of a Dutch study. Teacher Development, 2(1), 59-73.

Kormos, J., \& Csizér, K. (2014). The interaction of motivation, self-regulatory strategies, and autonomous learning behaviour in different learner groups. TESOL Quarterly, 48(2), 275-299.

Kubanyiova, M. (2009). Possible selves in language teacher development. In Z. Dornyei \& E. Ushioda (Eds.), Motivation, Language Identity and the L2 Self (pp. 314-332). Multilingual Matters.

Lamb, M. (2007). The impact of school on EFL learning motivation: An Indonesian case study. TESOL Journal, 41(4), 757-780.

Mahadi, T., \& Jafari, S. (2012). Motivation, its type, and its impacts in language learning. International Journal of Business and Social Science, 3(24), 230-235.

Mahmoodi, M. H., Kalantari, B., \& Ghaslani, R. (2014). Self-regulated learning, motivation and language achievement of Iranian EFL learners. Procedia-Social and Behavioral Sciences, 1062-1068.

Markus, H., \& Nurius, P. (1986). Possible selves. American Psychologist, 41(9), 954-969.

McCallum, F., \& Price, D. (2010). Well teachers, well students. Journal of Student Wellbeing, 4(1), $19-34$.

Mesthrie, R., \& Bhatt, R. M. (2008). World Englishes: The study of new linguistic varieties. Cambridge University Press.

Najeeb, S. S. (2013). Learner autonomy in language learning. Procedia-Social and Behaviour Science, 1238-1242.

Namaziandost, E., Neisi, L., Kheryadi., \& Nasri, M. (2019). Enhancing oral proficiency through cooperative learning among intermediate EFL learners: English learning motivation in focus. Cogent Education, 6(1), 1-15.

Nias, J. (1981). Teacher satisfaction and dissatisfaction: Herzberg's two-factor hypothesis revisited. British Journal of Sociology of Education, 2(3), 235-246.

Noels, K. A., Pelletier, L. G., Clément, R., \& Vallerand, R. J. (2000). Why are you learning a second language? Motivational Orientation and Self-Determination Theory. Language Learning, 50(1), $57-85$.

Osman, A. A. (2013). Freedom in teaching and learning. International Journal of Humanities and Social Science, 3(2), 142-149.

Pennycook, A. (1994). The cultural politics of English as an international language. Pearson Education.

Pintrich, P. R. (2000). The role of goal orientation in self-regulated learning. In M. Boekaerts, P. R. Pintrich, \& M. Zeidner (Eds.), Handbook of Self-Regulation (pp. 451-502). Academic.

Pintrich, P., \& Schunk, D. (2000). Motivation in education: Theory, research and applications. Upper Saddle.

Schunk, D. H. (2005). Self-Regulated Learning: The educational legacy of Paul R. Pintrich. Educational Psychologist, 40(2), 85-94. 
Seker, M. (2016). The use of self-regulation strategies by foreign language learners and its role in language achievement. Language Teaching Research, 20(5), 600-618.

Smith, R. (2008). Key concepts in ELT. ELT Journal, 62(4), 395-397.

Syamananda, P. (2017). Factors affecting EFL teachers' motivation in Thai university: a case study of EFL teachers at tertiary level. LEARN Journal: Language Education and Acquisition Research Network Journal, 10(2), 120-131.

Synder, H. (2019). Literature review as a research methodology: An overview and guidelines. Journal of Business Research, 104, 333-339.

Taguchi, T., Magid, M., \& Papi, M. (2009). The L2 motivational self system among Japanese, Chinese, and Iranian learners of English: A comparative study. In Z. Dörnyei \& E. Ushioda (Eds.), Motivation, Language Identity, and the L2 Self (pp. 66-97). Multilingual Matters.

Takahashi, T. (2018). Motivation of students for learning English in Rwandan schools. Issues in Educational Research, 28(1), 168-186.

Tranfield, D., Denyer, D., \& Smart, P. (2003). Towards a methodology for developing evidenceinformed management knowledge by means of systematic review. British Journal of Management, 14(3), 207-222.

Ushioda, E. (2011). Motivating learners to speak as themselves. In G. Murray, X. Gao, \& T. Lamb (Eds.), Identity, Motivation, and Autonomy in Language Learning (pp. 11-24). Multilingual Matters.

Ushioda, E., \& Dörnyei, Z. (2009). Motivation, language identities and the L2 self: A theoretical overview. In Z. Dörnyei \& E. Ushioda (Eds.), Motivation, Language Identity and the L2 Self (pp. 1-8). Multilingual Matters.

Wang, F. (2008). Motivation and English achievement: An Exploratory and Confirmatory Factor Analysis of a new measure for Chinese students of English learning. North America Journal of Psychology, 10(3), 633-646.

Webster, J., \& Watson, R. T. (2002). Analyzing the past to prepare for the future: Writing a literature review. Management Information Systems Quarterly, 26(2), 13-23.

Weiner, B., \& Peter, N. (1973). A Cognitive-Development Analysis of achievement and moral judgment. Developmental Psychology, 9(3), 290-309.

Weisz, J. R. (1980). Developmental change in perceived control: Recognizing noncontigency in the laboratory and perceiving it in the world. Developmental Psychology, 16(5), 385-390.

Wigfield, A., Zusho, A., \& De Groot, E. V. (2005). Introduction: Paul R. Pintrich's contribution to Educational Psychology: An enduring legacy. Educational Psychologist, 40(2), 67-74.

Yashima, T. (2009). International posture and the ideal L2 self in the Japanese EFL context. In Z. Dörnyei \& E. Ushioda (Eds.), Motivation, Language Identity and the L2 Self (pp. 144-163). Multilingual Matters.

Zhang, L. J., \& Xiao, Y. (2006). Language learning strategies, motivation EFL proficiency: A study of Chinese tertiary level non-english majors. Asian Englishes, 9(2), 20-47.

Zimmerman, B. J. (1989). Models of Self-Regulated Learning and academic achievement. In B. J. Zimmerman \& D. H. Schunk (Eds.), Self-Regulated Learning and Academic Achievement: Theory, Research, and Practice (pp. 1-38). Springer-Verlag. 